\title{
Screening of Endophytic Antagonistic Bacterium from Phellodendron amurense and Their Biocontrol Effects against Canker Rot
}

\author{
Shujiang $\mathrm{Li}^{\dagger}$, Xinmei Fang ${ }^{\dagger}$, Hanlian Zhang, Yanling Zeng, and Tianhui Zhu* \\ College of Forestry, Sichuan Agricultural University, Chengdu 611130, Sichuan Province, China \\ (Received on September 14, 2018; Revised on January 5, 2019; Accepted on February 17, 2019)
}

Thirty-four strains of bacteria were isolated from Phellodendron amurense. Using Nectria haematococca as an indicator strain, the best strain, B18, was obtained by the growth rate method. The morphological, physiological and biochemical characteristics of strain B18 and its 16S DNA gene sequence were identified, and the biocontrol effect of strain $B 18$ was assessed in pot and field tests, as well as in a field-control test. Drilling methods were used to determine the antibacterial activity of metabolites from strain B18 and their effects on the growth of pathogen mycelia and spores. The best bacteriostatic rate was $85.4 \%$. B18 can hydrolyse starch and oxidize glucose but does not produce gas; a positive result was obtained in a gelatine liquefaction test. According to 16S DNA gene sequencing, strain B18 is Bacillus methylotrophicus (GenBank accession number: MG457759). The results of pot and field-control trials showed $98 \%$ disease control when inoculating $10^{8} \mathrm{cfu} /$ $\mathrm{ml}$ of the strain. The disease control effect of the B18 culture liquid (concentrations of $10^{8}, 2 \times 10^{6}, 10^{6}, 5 \times 10^{5}$ and $\left.2.5 \times 10^{5} \mathrm{cfu} / \mathrm{ml}\right)$ in the field-control test was higher than $80 \%$, and the cure rate of the original delivery solution was $96 \%$. Therefore, in the practical forestry production, a $2.5 \times 10^{5} \mathrm{cfu} / \mathrm{ml}$ culture liquidshould be applied in advance to achieve good control effects.

Keywords : Bacillus methylotrophicus, biocontrol bacterium, canker rot, control efficiency, Nectria haematococca

\footnotetext{
${ }^{\dagger}$ These authors contributed equally to this study

*Corresponding author.

Phone) +86-028-86291456, FAX) +86-028-86291481

E-mail) zhuth1227@126.com

(c) This is an Open Access article distributed under the terms of the Creative Commons Attribution Non-Commercial License (http:// creativecommons.org/licenses/by-nc/4.0) which permits unrestricted noncommercial use, distribution, and reproduction in any medium, provided the original work is properly cited.
}

Articles can be freely viewed online at www.ppjonline.org.
Handling Editor : Sang, Mee Kyung

Phellodendron amurense is a deciduous tree of the family Rutaceaceae (Tang and Eisenbrand, 1992). Originating in northern China, South Korea and Japan, $P$. amurense has been cultivated in East Asia and Eastern Europe to produce bark for medicinal substances used as natural drugs, whereas the wood of this tree is used for furniture making and industrial art (Azad et al., 2005). This species is mainly distributed in Liaoning, Jilin, Heilongjiang and Inner Mongolia in China (Jiao et al., 2017). There is a long history of medicinal use of $P$. amurense, which has been listed in the Chinese Pharmacopoeia, with properties of reducing inflammation and preventing infection by pathogen fungi, as well as treating diarrhoea, jaundice, ulcers, lupus erythaematousus, eczema and other diseases (Tang and Eisenbrand, 1992). A recent study by Li et al. (2018) first reported Nectria haematococca to be a cause canker rot in P. amurense in a Huashan Forest Farm and Yangtianwo Drug Farm in Dayi County, Chengdu, Sichuan Province. This disease causes decaying of the trunk cortex, shedding of branches and wilting, affecting the yield of the medicinal materials, reducing the medicinal value and resulting in substantial loss.

At present, the main control method of plant diseases is the use of chemical pesticides. However, long-term use of chemical pesticides causes environmental pollution, and pesticide residues lead to an increase in disease resistance and reduced soil fertility (Passari et al., 2018). Moreover, chemical control causes the deterioration of natural resources, degradation of product quality, and destruction of ecological balance, with serious impacts on human health and ecological safety (Abbas et al., 2017). In contrast, biocontrol technology, which utilizes beneficial microorganisms to control the occurrence and development of disease, 
has been proposed as a solution (Iasur-Kruh et al., 2018). Indeed, the development of effective biological agents against pathogenic fungi is an important method to controlling plant diseases (Boukaew et al., 2017). Biocontrol bacteria are ubiquitous in the environment, with a wide range of prevention and control properties; furthermore, such bacteria exhibit good effects in controlling plant diseases, and there is no pathogen resistance. Thus, biocontrol bacteria are highly promising for plant disease control (Boukaew et al., 2017; Etesami and Alikhani, 2017; Kamal et al., 2016). Biocontrol microbes are abundant and include bacteria, fungi and actinomycetes (Baltz, 2016). The relevant bacteria are largely Pasteurella spp., Pseudomonas spp., Agrobacterium radiobacter and Bacillus spp. Among them, Bacillus spp. are known for their ability to control plant diseases through various mechanisms, including the production of secondary metabolites. Bacillus species, especially $B$. subtilis, B. cereus and Lactobacillus plantarum, are effective against plant diseases caused by soil transmission as well as leaf and post-harvest fungal pathogens (Yu et al., 2011). Most bacteria of the genus Bacillus are heat resistant, drought resistant and ultraviolet irradiation resistant (Obagwu et al., 2003). Almost all healthy plants contain endophytic bacteria, which colonize intercellular spaces and have many effects on host plants, such as promoting growth, preventing disease and fixing nitrogen. Accordingly, these bacteria are a natural resource for the biological control of plant diseases, with broad research value and development prospects. Some researchers have isolated antagonistic endophytic bacteria with good control effects against many diseases from a variety of plants, such as cotton, potato and pepper (Faltin et al., 2004).

To date, there have been few reports on canker rot in $P$. amurense in China and worldwide. Only Li et al. (2018) isolated and identified a causative pathogen: N. haematococca, whereas research on the screening of antagonistic bacteria from $P$. amurense and their application against canker rot has not yet been reported. In this study, endophytic bacteria were isolated and screened from healthy tissues of $P$. amurense from a forest farm and then assessed for their ability to effectively inhibit the pathogenic fungus responsible for canker rot in P. amurense. Morphological, physiological, biochemical and molecular characterizations were performed. The control effect was evaluated in pot and field experiments. The antimicrobial activity and mechanism of antagonistic strains were determined, and the effects of antagonistic strains on mycelial morphology and spore germination were determined. The aim of this study is to provide support for the development of new biocontrol agents for canker rot in $P$. amurense and to provide a more economical, efficient and environmentally friendly solution for prevention and control of this disease (Kumar and Hwang, 2006).

\section{Materials and Methods}

Materials. Plant samples and disease fungus: One-yearold healthy $P$. amurense seedlings were used. Healthy bark of $P$. amurense was collected from Huashan Forest Farm (Elevation $\left.1248 \mathrm{~m}, 30^{\circ} 37^{\prime} 01.1^{\prime \prime} \mathrm{N}, 103^{\circ} 18^{\prime} 46.1^{\prime \prime} \mathrm{E}\right)$ and Yangtianwo Drug Farm (Elevation 1260 m, 30 37'06.9"N, $\left.103^{\circ} 19^{\prime} 18.3^{\prime \prime} E\right)$ in Dayi County, Chengdu, Sichuan Province, China.

Fungus. The pathogenic fungus $N$. haematococca isolated from $P$. amurense canker rot was provided by the Key Laboratory of Forest Protection of Sichuan Province (Li et al., 2018).

Culture medium: (1) PDA: potato $200 \mathrm{~g}$, glucose $20 \mathrm{~g}$, agar 15-20 g, distilled water $1000 \mathrm{ml}, \mathrm{pH} 7.0$. Potato glucose agar was used for pathogen culture. (2) NA: peptone $10 \mathrm{~g}$, beef extract $3 \mathrm{~g}$, sodium chloride $5 \mathrm{~g}$, agar $15-20 \mathrm{~g}$, distilled water $1000 \mathrm{ml}, \mathrm{pH}$ 7.4-7.6. Beef peptone solid medium was used for the isolation and purification of bacteria.

Isolation of biocontrol endophytic bacteria. To isolate endophytic bacteria, the bark of $P$. amurense was disinfected with $70 \%$ alcohol and $3 \%$ sodium hypochlorite. The bark tissues were then washed several times with sterile water. The next step was to harvest the endophytic bacteria by the dilution separation method (Hornby, 1969). The thoroughly sterilized tissue was fully ground and diluted, and $10^{-3}, 10^{-4}$, and $10^{-5}$ dilutions of $100 \mu \mathrm{l}$ of the tissue solution were spread onto NA medium, and cultured for 1 $\mathrm{d}$ in a $3^{\circ} \mathrm{C}$ incubator to isolate single colonies distinctly different due to colony morphology.

Screening of antagonistic bacteria. According to the antagonistic bacterium screening method of Edwards and Mcbride (1975), antagonistic bacteria were preliminarily screened by the confrontation culture method. Strains with an obvious inhibition circle were selected, and their widths were measured. After purification, the strains were screened again. LB culture medium was selected for culture of antagonistic strains in a shaking bed incubator set at a constant temperature of $25^{\circ} \mathrm{C}$ and $135 \mathrm{r} / \mathrm{min}$ for $2 \mathrm{~d}$. The fermentation culture filtrate was collected and filtered through filter paper and centrifuged at 4,000 r/min for 8 $\mathrm{min}$, and the upper layer was filtered through a $0.22 \mu \mathrm{m}$ membrane to prepare a sterile culture filtrate. The growth 
rate method of Bekierkunst and Szulga (1954) was used to determine strain antagonism. LB plates spread with sterile water and no fermentation culture filtrate were used as a control. Samples were cultured at $25^{\circ} \mathrm{C}$ constant temperature, and the process was repeated three times.

Identification of antagonistic bacteria. Morphologic observation: The antagonistic bacterium was inoculated onto NA medium and cultured in an incubator at $25^{\circ} \mathrm{C}$. Morphological characteristics of colonies were assessed according to the Manual of Identification of the Common Bacterial System (Montanari et al., 2004; Zou et al., 2015).

Physiological and biochemical testing: The antagonistic bacterium was tested for Gram staining and spore staining as well as for the gelatine liquefaction test, nitrate reduction reaction, starch hydrolysis test, sugar oxidation fermentation test, contact enzyme reaction, acetyl methyl methanol test and hydrogen sulfide test.

Molecular biological identification: The strain was cultured in $20 \mathrm{ml}$ of NA liquid medium for $24 \mathrm{~h}$ under constant temperature shock. The culture liquid was collected into $2 \mathrm{ml}$ centrifuge tubes and centrifuged at $4^{\circ} \mathrm{C}$ and 12,000 rpm for $10 \mathrm{~min}$. DNA was extracted according to the bacterial genome DNA kit (Tiangen Biochemistry Technology Company of Limited Liability). The extracted DNA was amplified by Polymerase Chain Reaction using the bacterial $16 \mathrm{~S}$ rDNA universal primer (27F5'AGAGTTTGATCCTGGCTCAG-3') and (1492R5'GGTTACCTTGTTACGAC -T T-3').

Each $25 \mu$ l PCR mixture contained $0.5 \mu$ DNA template, $12.5 \mu 12 \times$ Taq Master Mix, $1 \mu$ each upstream and downstream primers, and $10 \mu \mathrm{ldd} \mathrm{H}_{2} \mathrm{O}$. The reaction consisted of a 4-min pre-denaturation at $94^{\circ} \mathrm{C}, 35$ cycles of denaturation $40 \mathrm{~s}$ at $94^{\circ} \mathrm{C}$, annealing $30 \mathrm{~s}$ at $55^{\circ} \mathrm{C}$, and extension for 1 min at $72^{\circ} \mathrm{C}$, and a $10 \mathrm{~min}$ final elongation at $72^{\circ} \mathrm{C}$. Five microlitres of the amplified product was assessed by $1 \%$ agarose gel electrophoresis and sequenced. The sequences were analysed by Blast homologous alignment, and the 16S rDNA sequences of highly homologous strains were downloaded from GenBank. Finally, a phylogenetic tree was constructed using the MEGA5.0 software adjacency method, and the phylogenetic status of the antagonistic strain was determined.

Determination of control effects in a pot experiment. The antagonistic bacterium was incubated for $48 \mathrm{~h}$ in NA liquid medium in a shaking bed incubator set at $28^{\circ} \mathrm{C}$ and $180 \mathrm{r} / \mathrm{min}$. The culture medium was prepared with different concentrations of $10^{4}, 10^{6}$, and $10^{8} \mathrm{cfu} / \mathrm{ml}$. Five pieces of pathogenic fungus mycelium $(\Phi=8 \mathrm{~mm})$ were obtained by the punch method and added to each bottle of PDA liquid medium; pathogen spores were at a concentration of $10^{5}$ / $\mathrm{ml}$ after $72 \mathrm{~h}$. One hundred healthy annual $P$. amurense seedlings were selected and divided into three groups, which were treated as follows: (1) plants were inoculated by wound inoculation with $20 \mathrm{ml}$ of pathogenic fungus suspension, and after $15 \mathrm{~d}, 20 \mathrm{ml}$ of antibiotic suspension at different concentrations was inoculated at the original site of inoculation by spraying (Sørensen et al., 2016); (2) plants were first treated with $20 \mathrm{ml}$ of antibiotic suspension at different concentrations for $15 \mathrm{~d}$ and then inoculated with $20 \mathrm{ml}$ of pathogen suspension; (3) plants were inoculated with different concentrations of antibiotic suspensions and $20 \mathrm{ml}$ pathogenic fungus suspension at the same time. Sterile water served as the control. Each treatment was repeated ten times. The disease was investigated with aseptic water and aseptic culture medium for $30 \mathrm{~d}$. The incidence, disease index and control effect were calculated. Disease was scored as follows: (I) no disease observed on the plant; (II) withering twigs less than $25 \%$; (III) withering twigs 25\%-50\%; (IV) withering twigs 51\%-75\%; and (V) withering twigs more than $75 \%$.

Field control. Field-control trials were conducted in a pure forest of $P$. amurense in Xieyuan Town, Dayi County, Chengdu City, Sichuan Province from July to August 2016. Two-year-old healthy $P$. amurense plants with similar growth potential were selected. A pathogen solution with a spore concentration of $10^{7} \mathrm{cfu} / \mathrm{ml}$ and culture filtrate with $10^{8} \mathrm{cfu} / \mathrm{ml}$ antagonistic bacterium were prepared. Concentrations of antibiotic solutions were $10^{8}, 2 \times 10^{6}, 10^{6}$, $5 \times 10^{5}, 2.5 \times 10^{5}$, and $1.25 \times 10^{5}$, respectively. The following three types of processing were performed. (1) The pathogen was inoculated into a wound in the middle of a branch. At 15 days after inoculation, the undiluted solution of antagonistic bacterium and the diluted bacterial solution were inoculated at the same site using the spraying method (Sørensen et al., 2016). (2) The antagonistic bacterium was inoculated in $15 \mathrm{~d}$ in advance by spraying the antagonistic bacterium and each bacterial dilution, after which the pathogen solution was inoculated at the original site. (3) Inoculation with the pathogen solution, original solution and diluted solution was performed at the same time. Using 30 plants per treatment, each pathogen and antagonist was inoculated in $100 \mathrm{ml}$. Sterile water and culture medium were used as controls, and field management was carried out according to standard practices. Disease development was evaluated at $50 \mathrm{~d}$ after treatment. The plants were rated for disease to determine the control effect in potted plants. 
Determination of the antagonistic mechanism of the antagonistic strain. Inhibitory effect of the antagonistic bacterium on the pathogenic fungus: (1) Effect on the mycelial growth of the pathogenic fungus - an antagonism test was carried out using the perforating method; sterile water was used as the control, and samples were assessed at $24,48,72,96$ and $120 \mathrm{~h}$ after addition of the antagonist supernatant. This assay was used to determine the diameter of the fungal colony and the diameter of the control fungal colony; each treatment was repeated 3 times. A growth curve of the disease after confrontation was drawn. After the control mycelium was covered with a flat plate, the difference between the mycelia of the surrounding colony and the normal mycelium of the control colony was observed under a light microscope (Hoyt et al., 2015). (2) Effects on the germination and production of spores by the pathogenic fungus: $10^{7} \mathrm{cfu} / \mathrm{ml}$ of spore suspension was prepared, and a sterile filtrate was obtained. A conidial suspension of 2 $\mu l$ of the pathogenic fungus was placed onto aseptic slides, and aseptic filtrates with an equal volume of concentrations of $1 \%, 5 \%, 25 \%$ and $50 \%$ were added to the conidial suspension droplets. Sterile water was used as the control, and the treatment was repeated 3 times. Conidial germination was detected at $5 \mathrm{~h}, 12 \mathrm{~h}$ and $24 \mathrm{~h}$ under the condition of moisture retention at $25 \%$. Germination of the spore bud tube was considered at more than $1 / 2$ of the spore diameter. (Sørensen et al., 2003). For each treatment, 200 spores were observed under a microscope; the total number of spores and number of sprouts were recorded, and the spore germination rate was calculated (Li et al., 2011).

Statistical analyses. All data were subjected to one-way analysis of variance to determine the significance of individual differences at the $P<0.05$ level. Significant means were compared using the least significant difference (LSD) test. All statistical analyses were conducted using the SPSS commercial statistical package (SPSS, Version 17.0 for Windows, SPSS Inc., Chicago, USA).

\section{Results}

Antagonistic effect. A total of 34 strains with different morphologies were isolated from healthy bark by tissue separation and named B1-B34. Five strains (B9, B18, B26, B30, and B34) with different inhibitory effects on the pathogenic fungus were screened by confrontation culture. The antagonistic effect of B18 was the best, with an inhibition rate of $85.4 \%$ (Table 1 ).

Identification of an antagonistic bacterium. Morphological characteristics: Strain B18 was positive for Gram staining. The cell is a long rod in shape, with a size of 0.7-0.8 $\mu \mathrm{m} \times 2.0-3.0 \mu \mathrm{m}$; endophytic spores formed are endophytic to secondary, elliptic or columnar, and slightly expanded (Supplementary Fig. 1). Physiological and biochemical properties: The results are shown in Table 2, referring to "Berger Manual of Bacterial Identification" (Fei et al., 2014). Strain B18 was identified as a member

Table 1. Inhibitory effects of five bacterial strains (culture 5 days)

\begin{tabular}{ccc}
\hline Strain & Inhibition zone diamter $(\mathrm{mm})$ & Inhibition rate $(\%)$ \\
\hline B9 & $15.0 \pm 0.10^{\mathrm{d}}$ & $36.4 \pm 0.21^{\mathrm{d}}$ \\
B18 & $43.0 \pm 0.62^{\mathrm{a}}$ & $85.4 \pm 0.32^{\mathrm{a}}$ \\
B26 & $37.7 \pm 0.38^{\mathrm{b}}$ & $69.7 \pm 0.42^{\mathrm{b}}$ \\
B30 & $36.7 \pm 0.15^{\mathrm{b}}$ & $70.1 \pm 0.12^{\mathrm{b}}$ \\
B34 & $29.7 \pm 0.31^{\mathrm{c}}$ & $52.6 \pm 0.22^{\mathrm{c}}$ \\
\hline
\end{tabular}

Data are the means \pm SD $(n=3)$. Lowercase letters after the same column indicate a significant difference among the strains at $P<0.05$ by the LSD test.

Table 2. Physiological and biochemical characteristics of strain B18

\begin{tabular}{ccc}
\hline Item & Reaction type & Remarks \\
Gram stain & + & - \\
Spore stain & + & + \\
Contact enzyme reaction & + & Producing colourless transparent bubbles \\
Acetyl methyl methanol test & + & The medium was completely liquefied after 30 days \\
Gelatine liquefaction experiment & + & Pink compound \\
Nitrate reduction reaction & - & - \\
Hydrogen sulfide production test & - & - \\
Citrate test & + & Glycine medium was slightly green \\
Starch hydrolysis test & + & - \\
\hline
\end{tabular}

"+" indicates positive; "-" indicates negative. 


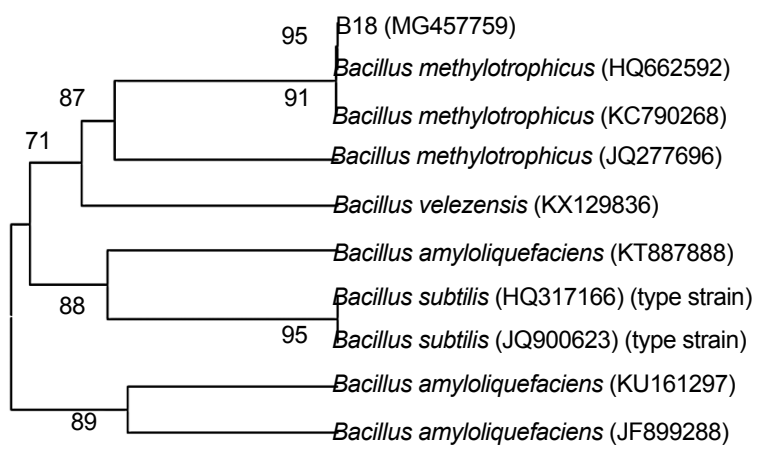

$0.020 \longmapsto$

Fig. 1. Neighbour-joining tree based on analysis of partial 16S rDNA nucleotide sequences of the selected bacterial strain B18. The percentage of replicate trees in which associated taxa clustered together in the bootstrap test (1000 replicates) is shown next to the branches. The tree is drawn to scale, with branch lengths in the same units as those of the evolutionary distances used to infer the phylogenetic tree. Evolutionary distances were computed using the Kimura 2-parameter method (Kimura, 1980); the results are presented in units of the number of base substitutions per site. In phylogenetic tree, Bacillus subtilis is one type strain.

of the Bacillus genus and further identified by $16 \mathrm{~S}$ rDNA sequence analysis. rDNA-ITS sequence analysis of antagonistic bacteria: 16S rDNA sequence primers $(1492 \mathrm{R} / 27 \mathrm{~F})$ of bacteria were used for PCR followed by agarose gel electrophoresis; the results are shown in Supplementary Fig. 2. The amplified product was sequenced, and an rDNA-ITS sequence of length 959 bp (GenBank accession number: MG457759) was obtained. The obtained sequence was analysed by homology BLAST with sequences reported in GenBank. A phylogenetic tree was constructed with MEGA5.0 analysis software (Fig. 1). The B18 strain and B. methylotrophicus (GenBank numbers: HQ662593 and KC790268) exhibit 99\% nucleotide sequence similarity; a higher self-spreading value supports one branch far from other members of Bacillus. Therefore, strain B18 was identified as B. methylotrophicus.

Determination of control effects on potted plants. The control effects after inoculation with the B18 strain for 30 days in pot experiments are shown in Table 3, presenting symptoms such as those depicted in Supplementary Fig. 3. At a concentration of $10^{4} \mathrm{cfu} / \mathrm{ml}$, the cortex of $P$. amurense was nearly half rotten; leaves were dry, and a few were dead. Under the same conditions, bacterial inoculation in advance conferred the best control.

Field control. The control effects at 15 days after spraying treatment are shown in Table 4. The cure rate of the original was up to $96 \%$. Better than $80 \%$ control was observed with concentrations of $10^{8}, 2 \times 10^{6}, 5 \times 10^{5}$ and $2.5 \times 10^{5}$ $\mathrm{cfu} / \mathrm{ml}$, and the difference was not significant. The control effect of the concentration of $1.25 \times 10^{5} \mathrm{cfu} / \mathrm{ml}$ was significantly reduced to approximately $66 \%$; while the disease was serious in the negative control group.

Antagonistic mechanism of the antagonistic strain. A growth curve of the pathogenic fungus (Fig. 2A) based on confrontation culture (Fig. 2B) was generated according to culture time, and the control group mycelium continued to increase in size. The colour of the mycelium and culture medium of the pathogenic fungus gradually deepened and darkened due to a control effect. Under an optical microscope, the morphology of the marginal mycelium of the inhibited colony was destroyed, mainly manifesting as swelling of the mycelium and deformity of the conidium.

Table 3. Control effect of the endophytic bacterium strain B18 after 30 days in a pot experiment

\begin{tabular}{|c|c|c|c|c|c|c|c|c|c|}
\hline \multirow{2}{*}{$\begin{array}{c}\text { Bacterial } \\
\text { Concentra- } \\
\text { tion } \\
(\mathrm{cfu} / \mathrm{ml})\end{array}$} & \multicolumn{3}{|c|}{$\begin{array}{l}\text { Inoculation with pathogenic } \\
\text { fungus first }\end{array}$} & \multicolumn{3}{|c|}{$\begin{array}{l}\text { Inoculation with biocontrol } \\
\text { bacterium first }\end{array}$} & \multicolumn{3}{|c|}{ Simultaneous inoculation } \\
\hline & $\begin{array}{l}\text { Incidence } \\
(\%)\end{array}$ & $\begin{array}{l}\text { Disease } \\
\text { index }\end{array}$ & $\begin{array}{c}\text { Control } \\
\text { effect }(\%)\end{array}$ & $\begin{array}{c}\text { Incidence } \\
(\%)\end{array}$ & $\begin{array}{l}\text { Disease } \\
\text { index }\end{array}$ & $\begin{array}{c}\text { Control } \\
\text { effect }(\%)\end{array}$ & $\begin{array}{l}\text { Incidence } \\
(\%)\end{array}$ & $\begin{array}{l}\text { Disease } \\
\text { index }\end{array}$ & $\begin{array}{c}\text { Control } \\
\text { effect }(\%)\end{array}$ \\
\hline $10^{4}$ & $46.0 \pm 0.5^{b}$ & $32.4 \pm 0.2^{\mathrm{c}}$ & $50.0 \pm 0.5^{c}$ & $35.0 \pm 0.3^{b}$ & $20.0 \pm 0.5^{\mathrm{c}}$ & $59.0 \pm 0.2^{c}$ & $39.0 \pm 0.1^{\mathrm{b}}$ & $24.1 \pm 0.3^{\mathrm{c}}$ & $56.0 \pm 0.2^{c}$ \\
\hline $10^{6}$ & $20.0 \pm 0.5^{\mathrm{c}}$ & $14.3 \pm 0.2^{b}$ & $78.0 \pm 0.4^{b}$ & $14.0 \pm 0.2^{\mathrm{c}}$ & $7.8 \pm 0.3^{b}$ & $84.0 \pm 0.1^{b}$ & $18.0 \pm 0.1^{\mathrm{c}}$ & $10.9 \pm 0.2^{b}$ & $80.0 \pm 0.6^{b}$ \\
\hline $10^{8}$ & $5.0 \pm 0.3^{\mathrm{d}}$ & $3.9 \pm 0.2^{\mathrm{d}}$ & $94.0 \pm 0.5^{\mathrm{a}}$ & $2.0 \pm 0.3^{\mathrm{d}}$ & $0.9 \pm 0.4^{\mathrm{a}}$ & $98.0 \pm 0.6^{\mathrm{a}}$ & $4.0 \pm 0.2^{\mathrm{d}}$ & $2.6 \pm 0.1^{\mathrm{d}}$ & $95.0 \pm 0.2^{\mathrm{a}}$ \\
\hline Control & $92.0 \pm 0.4^{\mathrm{a}}$ & $64.8 \pm 0.3^{\mathrm{a}}$ & - & $86.0 \pm 5^{\mathrm{a}}$ & $48.8 \pm 0.4^{\mathrm{d}}$ & - & $89.0 \pm 0.3^{\mathrm{a}}$ & $54.9 \pm 0.4^{\mathrm{a}}$ & - \\
\hline
\end{tabular}

Data are the means \pm SD $(\mathrm{n}=10)$. Lowercase letters after the same column indicate a significant difference among bacterial concentrations at $P<0.05$ by the LSD test.

Incidence $(\%)=($ number of infected plants/total number of inoculated plants $) \times 100$;

Disease index $=[\Sigma$ (numerical value of each disease rating $\times$ number of twigs for each disease rating $) /($ total twigs $\times$ most serious disease rating) $] \times 100$;

Control effect $(\%)=[\Sigma($ control disease index-treatment disease index $) /$ control disease index $] \times 100$. 
Table 4. Effect of the endophytic bacterium strain B18 on canker rot in Phellodendron amurense in a field experiment

\begin{tabular}{|c|c|c|c|c|c|c|c|c|c|}
\hline \multirow{2}{*}{$\begin{array}{c}\text { Bacterial } \\
\text { Concentra- } \\
\text { tion } \\
(\mathrm{cfu} / \mathrm{ml})\end{array}$} & \multicolumn{3}{|c|}{$\begin{array}{l}\text { Inoculation with pathogenic } \\
\text { fungus first }\end{array}$} & \multicolumn{3}{|c|}{$\begin{array}{l}\text { Inoculation with biocontrol } \\
\text { bacterium first }\end{array}$} & \multicolumn{3}{|c|}{ Simultaneous inoculation } \\
\hline & $\begin{array}{l}\text { Incidence } \\
(\%)\end{array}$ & $\begin{array}{l}\text { Disease } \\
\text { index }\end{array}$ & $\begin{array}{c}\text { Control } \\
\text { effect }(\%)\end{array}$ & $\begin{array}{l}\text { Incidence } \\
\qquad(\%)\end{array}$ & $\begin{array}{l}\text { Disease } \\
\text { index }\end{array}$ & $\begin{array}{c}\text { Control } \\
\text { effect }(\%)\end{array}$ & $\begin{array}{l}\text { Incidence } \\
\qquad(\%)\end{array}$ & $\begin{array}{l}\text { Disease } \\
\text { index }\end{array}$ & $\begin{array}{c}\text { Control } \\
\text { effect }(\%)\end{array}$ \\
\hline & $7.0 \pm 0.5^{\mathrm{g}}$ & $6.1 \pm 0.4$ & $1.0 \pm 0.3^{\mathrm{a}}$ & $3.0 \pm 0.1^{\mathrm{f}}$ & $1.9 \pm 0.2^{\mathrm{g}}$ & $96.0 \pm 0.2^{\mathrm{a}}$ & & $2.7 \pm 0.2^{\mathrm{g}}$ & $95.0 \pm 0.2^{\mathrm{a}}$ \\
\hline & $10.0 \pm 0.4^{\mathrm{f}}$ & $6.8 \pm 0.2^{\mathrm{g}}$ & $90.0 \pm 0.3^{\mathrm{a}}$ & $5.0 \pm 0.2^{\mathrm{f}}$ & & & & & $92.0 \pm 0.4^{\mathrm{b}}$ \\
\hline $10^{6}$ & $13.0 \pm 0.2^{\mathrm{e}}$ & & & & & & $10.0 \pm 0.4^{\mathrm{e}}$ & $5.9 \pm 0.1^{\mathrm{e}}$ & \\
\hline $5 \times 10^{5}$ & $17.0 \pm 0.5^{\mathrm{d}}$ & $11.5 \pm 0.2^{\mathrm{d}}$ & $83.0 \pm 0.2^{\mathrm{c}}$ & $12.0 \pm 0.3^{\mathrm{d}}$ & $5.2 \pm 0.2^{\mathrm{d}}$ & $89.0 \pm 0.2^{\mathrm{c}}$ & $14.0 \pm 0.2^{\mathrm{e}}$ & & \\
\hline $2.5 \times 10^{5}$ & $21.0 \pm 0.3^{\mathrm{c}}$ & $3.5 \pm 0.2^{c}$ & $80.0 \pm 0.5^{\mathrm{d}}$ & $16.0 \pm 0.3^{\mathrm{c}}$ & $7.1 \pm 0.1^{\mathrm{c}}$ & $85.0 \pm 0.1^{\mathrm{d}}$ & $18.0 \pm 0.2^{\mathrm{c}}$ & $9.7 \pm 0.4^{\mathrm{c}}$ & $82.0 \pm 0.3^{\mathrm{c}}$ \\
\hline $1.25 \times 10^{5}$ & $39.0 \pm 0.4^{\mathrm{b}}$ & $26.3 \pm 0.4^{\mathrm{b}}$ & $61.0 \pm 0.2^{\mathrm{c}}$ & $28.0 \pm 0.5^{\mathrm{b}}$ & $13.3 \pm 0.3^{b}$ & $72.0 \pm 0.2^{\mathrm{c}}$ & $34.0 \pm 0.2^{\mathrm{b}}$ & $18.3 \pm 0.3^{\mathrm{b}}$ & $66.0 \pm 0.5^{\mathrm{f}}$ \\
\hline Control & $96.0 \pm 0.4^{\mathrm{a}}$ & $67.5 \pm 0.3^{\mathrm{a}}$ & - & $89.0 \pm 0.4^{\mathrm{a}}$ & $47.6 \pm 0.4^{\mathrm{d}}$ & - & $93.0 \pm 0.4^{\mathrm{a}}$ & $53.9 \pm 0.4^{\mathrm{a}}$ & - \\
\hline
\end{tabular}

Data are the means \pm SD $(n=30)$. Lowercase letters after the same column indicate a significant difference among dilutions of B18 culture liquid at $P<0.05$ by the LSD test.

A

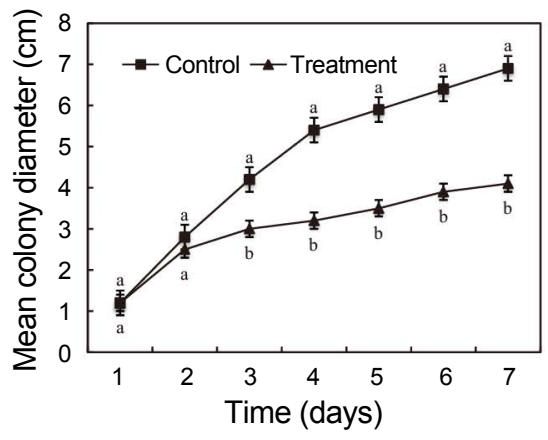

C

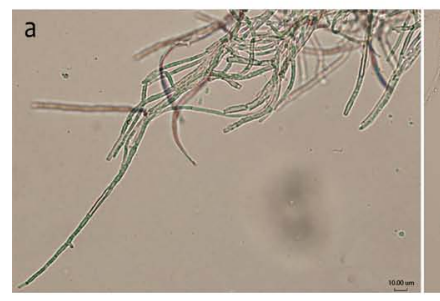

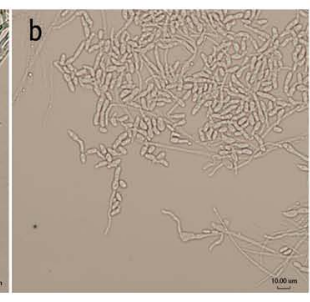

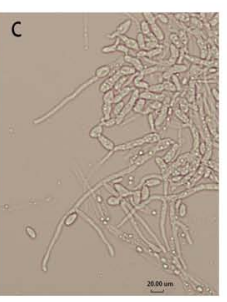

B

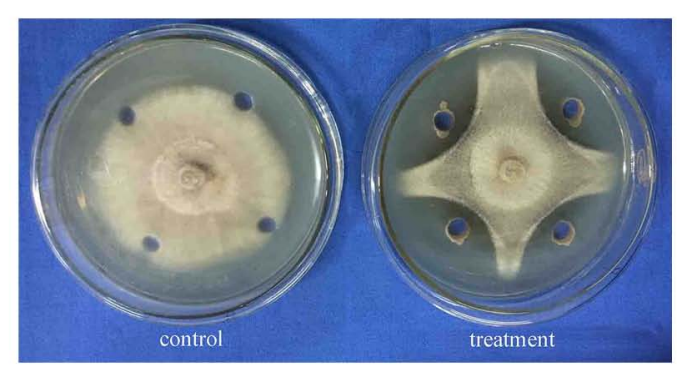

D

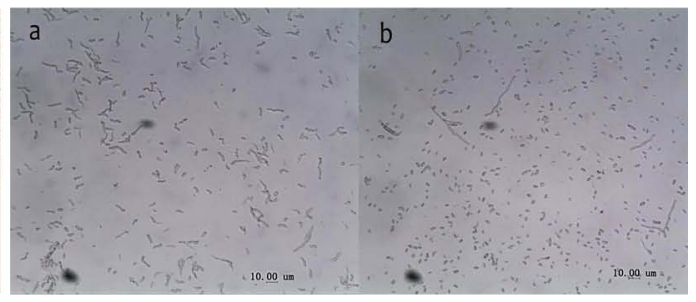

Fig. 2. Antagnistic effect of culture filtrate of B. methylotrophicus B18. (A) Growth inhibition curve by the B18 solution on mycelium of the pathogenic fungusError bars indicate means $\pm \mathrm{SD}(n=3)$; ddifferent lowercase letters indicate significant difference between controls and treatments at different times at $P<0.05$ by the LSD test. (B) Antagonistic effect of the B18 bacterial solution (10 cfu/ml) against a pathogenic fungus. (C) Effect of the fermentation sterile culture filtrate on mycelial morphology of the pathogenic fungus. a: Normal mycelium; b: The concentration of biocontrol bacteria B18 is $10^{6} \mathrm{cfu} / \mathrm{ml}$; $\mathrm{c}$ : The concentration of biocontrol bacteria B18 is $10^{8} \mathrm{cfu} / \mathrm{ml}$. (D) Effect of the fermentation sterile culture filtrate on spores of the pathogenic fungus. a: Germination of spores at a concentration of $1 \%$; $b$ : Germination of spores at a concentration of $50 \%$.

In contrast, the mycelia of the control group were vigorous and well developed (Fig. 2C). The results of the spore germination test are shown in Table 5. The B18 sterile culture filtrate demonstrated a distinct inhibitory effect on germination of the pathogen (Fig. 2D), whereas the spores in the control group were able to germinate normally. The germination rate was $77 \%$.

\section{Discussion}

The beneficial bacteria of healthy plant tissue play an important role in controlling plant diseases. In this study, 34 strains of bacteria were isolated from the bark of healthy $P$. amurense, and 5 strains with different inhibitory effects against canker rot in $P$. amurense were screened by 
Table 5. Inhibitory effect of B18 sterile culture filtrate on the germination of Nectria haematococca spores

\begin{tabular}{|c|c|c|c|c|c|c|}
\hline \multirow{2}{*}{$\begin{array}{l}\text { Concentration } \\
\text { of sterile culture } \\
\text { filtrate }(\%)\end{array}$} & \multicolumn{2}{|c|}{$5 \mathrm{~h}$} & \multicolumn{2}{|c|}{$12 \mathrm{~h}$} & \multicolumn{2}{|c|}{$24 \mathrm{~h}$} \\
\hline & $\begin{array}{c}\text { Germination rate } \\
(\%)\end{array}$ & $\begin{array}{c}\text { Germination } \\
\text { inhibition rate }(\%)\end{array}$ & $\begin{array}{c}\text { Germination } \\
\text { rate }(\%)\end{array}$ & $\begin{array}{c}\text { Germination } \\
\text { inhibition rate }(\%)\end{array}$ & $\begin{array}{c}\text { Germination } \\
\text { rate }(\%)\end{array}$ & $\begin{array}{c}\text { Germination } \\
\text { inhibition rate }(\%)\end{array}$ \\
\hline 1 & $1.4 \pm 0.5^{\mathrm{ab}}$ & $6.7 \pm 0.9^{b}$ & $11.3 \pm 3.5^{\mathrm{b}}$ & $43.5 \pm 2.0^{\mathrm{b}}$ & $30.4 \pm 1.2^{b}$ & $60.5 \pm 2.5^{\mathrm{b}}$ \\
\hline 5 & $1.2 \pm 0.4^{\mathrm{abc}}$ & $20.0 \pm 1.2^{\mathrm{ab}}$ & $8.8 \pm 3.9^{b}$ & $56.0 \pm 1.6^{\mathrm{ab}}$ & $22.5 \pm 1.7^{\mathrm{c}}$ & $70.8 \pm 1.4^{\mathrm{a}}$ \\
\hline 25 & $1.1 \pm 0.4^{\mathrm{bc}}$ & $26.7 \pm 2.4^{\mathrm{ab}}$ & $7.6 \pm 0.5^{\mathrm{b}}$ & $62.0 \pm 2.1^{\mathrm{a}}$ & $20.2 \pm 1.8^{\mathrm{cd}}$ & $73.8 \pm 2.2^{\mathrm{a}}$ \\
\hline 50 & $0.8 \pm 0.5^{\mathrm{c}}$ & $46.7 \pm 4.3^{\mathrm{a}}$ & $7.3 \pm 0.5^{b}$ & $63.5 \pm 3.4^{\mathrm{a}}$ & $18.3 \pm 0.9^{\mathrm{d}}$ & $76.2 \pm 2.6^{\mathrm{a}}$ \\
\hline Control & $1.5 \pm 0.3^{\mathrm{a}}$ & - & $20.0 \pm 5.0^{\mathrm{a}}$ & - & $77.0 \pm 2.4^{\mathrm{a}}$ & - \\
\hline
\end{tabular}

Data are the means $\pm \mathrm{SD}(\mathrm{n}=3)$. Lowercase letters after the same column indicate a significant difference among the concentrations of fermentation filtrate at $P<0.05$ by the LSD test.

Germination rate $(\%)=$ number of germination spores/total treatment spores;

Germination inhibition rate $(\%)=$ (number of germination spores in control- number of germination of spores in treatment)/number of germination spores in control $\times 100$.

confrontation culture. The growth rate method was used to identify the best strain, B18, inhibiting the mycelial growth of canker rot in P. amurense. Morphological and molecular identification was carried out to examine the physiological and biochemical characteristics of this strain, and its control effects in potted plants and in the field were evaluated. The strain was identified as B. methylotrophicus by $16 \mathrm{~S}$ rDNA analysis, and the strain showed strong antibacterial activity against the investigated pathogen. We also evaluated some interesting physiological and biochemical characteristics and biological activity. Bacillus-like bacteria can be isolated from the epidermis of healthy plant tissues, and many studies have shown that these microbes are antagonistic to many plant disease agents. However, biological control of B. methylotrophicus has not yet been studied. By investigating biocontrol effects, we can lay a theoretical foundation for the development of efficient and stable biological control agents.

The five strains exhibited more than 50\% inhibition of the growth of $N$. haematococca. Strain B18, identified as $B$. methylotrophicus, inhibited the growth of $N$. haematococca mycelia. It has been reported that biocontrol bacteria can inhibit the growth of mycelia as well as the conidial germination of many plant pathogenic fungi in vitro, which is similar to the results of this study. A greenhouse test showed that inoculation with Bacillus grisea conferred $89.87 \%$ biocontrol, and the results of field experiments indicated that the filtrate of B. methylotrophicus had the highest fungistatic effect against Aspergillus oryzae, with $84.8 \%$ biological control (Shan et al., 2013). In this study, pot experiment showed better disease prevention with increasing concentrations of strain B18, with the best effect at $10^{8} \mathrm{cfu} / \mathrm{ml}$ inoculation concentration. Similarly, in our field control analysis, the cure rate of canker rot in P. amurense was up to $96 \%$, and the preventive effect decreased with increasing dilution of B18. In the pot and field trials in this study, B. methylotrophicus was inoculated in advance, and then the pathogenic fungus responsible for canker rot was inoculated; the best control effects were $98 \%$ and $96 \%$, respectively, demonstrating broad prospects for development. Sun et al. (2016) found that B. methylotrophicus could control Microcystis aeruginosa and that the supernatant of the strain disrupted the cell membrane via oxidation, affecting membrane permeability; this bacterium has been used in an algaecide. Frikha-Gargouri et al. (2017) found that $B$. methylotrophicus had antimicrobial activity against Agrobacterium tumefaciens. In vitro, it was found that $B$. methylotrophicus could inhibit the growth of tomato crown gall disease pathogens.

Several studies have shown that B. methylotrophicus can produce a variety of metabolites with different functions. Zhang et al. (2014) found that B. methylotrophicus produces levosucrase and levopectin, and Chandankere et al. (2013) reported that B. methylotrophicus produces a biosurfactant with excessive foam formation. B. methylotrophicus strain USTBa represents an effective producer of biosurfactants and can be used in various biotechnology and industrial processes, especially in the petroleum industry. Chandankere et al. (2014) also used crude oil as the only carbon source and separated this effective bioactive agent-producing and hydrocarbon-degrading bacterium from the hydrocarbon pollution. Peng et al. (2015) was the first to prove that $B$. methylotrophicus can produce high levels of gamma-polyglutamic acid ( $\gamma$-PGA), which has a great moisturizing effect and is not harmful to humans and accordingly is widely used in cosmetic manufacturing. Pérezflores et al. (2017) found that the increase in volatile production by $B$. methylotrophicus can lead to an increase in auxin content in Arabidopsis thaliana. In the present study, the growth rate method was used to determine the 
strong inhibitory effect of the B. methylotrophicus fermentation culture filtrate on the hyphal growth of $N$. haematococca mycelia. Strain B18 exhibited high biocontrol ability, meeting the screening criteria of an ideal biocontrol agent, and has a certain development potential. This study is a solid first step in developing an effective biocontrol agent for canker rot in $P$. amurense, but the exact mechanism by which the biological control bacterium strain B18 suppresses the growth of the pathogenic fungus remains to be further studied.

\section{Acknowledgements}

This research was supported financially by National Natural Science Foundation of China (31700568) and China Postdoctoral Science Foundation (2016M602705).

\section{References}

Abbas, T., Zahir, Z. A. and Naveed, M. 2017. Bioherbicidal activity of allelopathic bacteria against weeds associated with wheat and their effects on growth of wheat under axenic conditions. BioControl 62:719-730.

Azad, M. A. K., Yokota, S., Ohkubo, T., Andoh, Y., Yahara, S. and Yoshizawa, N. 2005. In vitro, regeneration of the medicinal woody plant Phellodendron amurense Rupr. through excised leaves. Plant Cell Tissue Organ Cult. 80:43-50.

Baltz, R. H. 2016. Genetic manipulation of secondary metabolite biosynthesis for improved production in Streptomyces and other actinomycetes. J. Ind. Microbiol. Biotechnol. 43:343370 .

Bekierkunst, A. and Szulga, T. 1954. A new method for determining the growth rate of $M$. tuberculosis and its application to the study of the toxic effects of Streptomycin and isonicotinic hydrazide acid on tubercle bacilli. Schweiz. Z. Pathol. Bakteriol. 17:47-72.

Boukaew, S., Prasertsan, P., Troulet, C. and Bardin, M. 2017. Biological control of tomato gray mold caused by Botrytis cinerea, by using Streptomyces spp.. BioControl 62:793-803.

Chandankere, R., Yao, J., Choi, M. M. F., Masakorala, K. and Chan, Y. 2013. An efficient biosurfactant producing and crude-oil emulsifying bacterium Bacillus methylotrophicus USTBa isolated from petroleum reservoir. Biochem. Eng. J. 74:46-53.

Chandankere, R., Yao, J., Cai, M., Masakorala, K., Jain, A. K. and Choi, M. M. F. 2014. Properties and characterization of biosurfactant in crude oil biodegradation by bacterium Bacillus methylotrophicus USTBa. Fuel 122:140-148.

Edwards, T. and McBride, B. C. 1975. New method for the isolation and identification of methanogenic bacteria. Appl. Microbiol. 29:540-545.

Etesami, H. and Alikhani, H. A. 2017. Evaluation of gram- positive rhizosphere and endophytic bacteria for biological control of fungal rice (Oryzia sativa, L.) pathogens. Eur. J. Plant Pathol. 147:7-14.

Faltin, F., Lottmann, J., Grosch, R. and Berg, G. 2004. Strategy to select and assess antagonistic bacteria for biological control of Rhizoctonia solani Kuhn. Can. J. Microbiol. 50:811-820.

Fei, Y. T., Liu, D. M., Luo, T. H., Chen, G., Wu, H., Li, L. and Yu, Y. G. 2014. Molecular characterization of Lactobacillus plantarum DMDL 9010, a strain with efficient nitrite degradation capacity. PLoS One 9:e113792.

Frikha-Gargouri, O., Abdallah, D. B., Ghorbel, I., Charfeddine, I., Jlaiel, L., Triki, M. A. and Tounsi, S. 2017. Lipopeptides from a novel Bacillus methylotrophicus 39b strain suppress Agrobacterium crown gall tumours on tomato plants. Pest Manag. Sci. 73:568-574.

Hornby, D. 1969. Gravimetrical and mycological investigations of soil suspensions in the soil dilution plate technique. $J$. Appl. Bacteriol. 32:244-258.

Hoyt, J. R., Cheng, T. L., Langwig, K. E., Hee, M. M., Frik, W. F. and Kilpatrict A. M. 2015. Bacteria isolated bats inhibit growth of Pseudogymnoascus destructans, the causative agent of white-nose syndrome. PLoS One 10:e121329.

Iasur-Kruh, L., Zahavi, T., Barkai, R., Freilich, S., Zchori-Fein, E. and Naor, V. 2018. Dyella-Like bacterium isolated from an insect as a potential biocontrol agent against Grapevine yellows. Phytopathology 108:336-341.

Jiao, W., Zhou, R., Fu, J., Xu, H. and Hao, N. 2017. First report of Nothophoma quercina causing leaf spot disease of Phellodendron amurense in China. Plant Dis. 101:1820.

Kamal, M. M., Lindbeck, K. D., Savocchia, S. and Ash, G. J. 2016. Biological control of Sclerotinia stem rot of canola using antagonistic bacteria. Plant Pathol. 64:1375-1384.

Kimura, M. 1980. A simple method for estimating evolutionary rate of base substitutions through comparative studies of nucleotide sequences. J. Mol. Evol. 16:111-120.

Kumar, R. and Hwang, J. S. 2006. Larvicidal efficiency of aquatic predateors: A perspective for mosquito biocontrol. Zoological Stud. 45:447-466.

Li, S. J., Cui, Y. T., Fang, X. M., He, Q. Q., Zhu, T. H., Qiao, T. M. and Han, S. 2018. First report of Nectria haematococca as the causal agent of canker rot in Phellodendron amurense in China. Plant Dis. 102:1033.

Montanari, G., Borsari, A., Chiavari, C., Ferri, G., Zambonelli, C. and Grazia, L. 2004. Morphological and phenotypical characterization of Bacillus sporothermodurans. J. Appl. Microbiol. 97:802-809.

Obagwu, J. and Korsten, L. 2003. Integrated control of citrus green and blue molds using Bacillus subtilis in combination with sodium bicarbonate or hot water. Postharvest Biol. Technol. 28:187-194.

Passari, A. K., Lalsiamthari, P. C., Zothanpuia, Leo, V. V., Mishra, V. K., Yadav, M. K., Gupta, V. K. and Singh, B. P. 2018. Biocontrol of Fusarium wilt of Capsicum annuum by rhizospheric bacteria isolated from turmeric endowed with plant 
growth promotion and disease suppression potential. Eur. J. Plant Pathol. 150:831-846.

Peng, Y., Jiang, B., Zhang, T., Mu, W., Miao, M. and Hua, Y. 2015 . High-level production of poly ( $\gamma$-glutamic acid) by a newly isolated glutamate-independent strain Bacillus methylotrophicus. Process Biochem. 50:329-335.

Pérez-Flores, P., Valencia-Cantero, E., Altamirano-Hernández, J., Pelagio-Flores, R., López-Bucio, J., García-Juárez, P. and Macías-Rodríguez, L. 2017. Bacillus methylotrophicus M496 isolated from maize (Zea mays) rhizoplane increases growth and auxin content in Arabidopsis thaliana via emission of volatiles. Protoplasma 254:2201-2213.

Shan, H., Zhao, M., Chen, D., Cheng, J., Li, J., Feng, Z., Ma, Z. and An, D. 2013. Biocontrol of rice blast by the phenaminomethylacetic acid producer of Bacillus methylotrophicus strain BC79. Crop Prot. 44:29-37.

Sun, P., Hui, C., Wang, S., Khan, R. A., Zhang, Q. and Zhao, Y. H. 2016. Enhancement of algicidal properties of immobilized Bacillus methylotrophicus ZJU by coating with magnetic $\mathrm{Fe}_{3} \mathrm{O}_{4}$ nanoparticles and wheat bran. J. Hazard. Mater.
301:65-73.

Sørensen, C. K., Thach, T. and Hovmøller, M. S. 2016. Evaluation of spray and point inoculation methods for the phenotyping of Puccinia striiformis on wheat. Plant Dis. 100:10641070.

Tang, W. and Eisenbrand, G. 1992. Phellodendron amurense Rupr. In: Chinese drugs of plant origin, eds. by W. Tang and G. Eisenbrand, pp. 759-762. Springer-Verlag, Berlin, Germany.

Yu, X., Ai, C., Xin, L. and Zhou, G. 2011. The siderophore-producing bacterium, Bacillus subtilis CAS15, has a biocontrol effect on Fusarium wilt and promotes the growth of pepper. Eur. J. Soil Biol. 47:138-145.

Zhang, T., Li, R., Qian, H., Mu, W., Miao, M. and Jiang, B. 2014. Biosynthesis of levan by levansucrase from Bacillus methylotrophicus SK 21.002. Carbohydr. Polym. 101:975-981.

Zou, C. L., Zhao, G. C., Jiang, Y. C., Lin, D. Q. and Gu, X. Y. 2015. Screening of a flocculent acetic acid degrading bacterium and its degradative characteristics. J. Nanjing Agric. Univ. 38:830-837. 